\title{
Research on the Legislation Protection of Taxpayer's Right to Presumption of Honesty
}

\author{
Yanwei Zhang \\ China Jiliang University \\ Hangzhou, China
}

\begin{abstract}
The taxpayer's right to presumption of honesty is a basic right of the taxpayer, and it is the concrete manifestation of human rights protection in the field of tax law. Due to the influence of the "executive-led" tax collection and management system in China, this right has not been stipulated in the law. Although the "Revised Draft Tax Collection Management Law" (Draft for Comment) in 2015 has strengthened the taxpayers' rights awareness to a certain extent, the degree of protection for the rights of taxpayers is still far from sufficient, and the problem of tax evasion and the abuse of power by other tax collectors is becoming more and more serious. This paper will study the concept of taxpayer's right to presumption of honesty, the background research, the significance of the establishment of the system, and the analysis of the status quo of the implementation of the taxpayer's right to presumption of honesty in China, the legislative protection of the territorial taxpayer's right to presumption of honesty, and the enlightenment to China, to make a concrete analysis for the establishment of China's taxpayer's right to presumption of honesty structure.
\end{abstract}

Keywords-taxpayer; right to presumption of honesty; taxpayer rights

\section{INTRODUCTION}

Franklin, a famous American writer and politician, has a famous saying: "Two things are inevitable in a person's life. One is death and the other is tax payment." Taxation is both a legal obligation and a legal right. The taxpayer's right to presumption of honesty is the basic right of the taxpayer, and it is the basic embodiment of the personality right in the tax collection and management. But now, a series of practical problems, such as the increase in tax evasion and the abuse of power by tax collectors, have led to the suspicion of the tax management concept that has been implemented, and because of the "appearance without reality" of the taxpayer's right to presumption of honesty, it makes people can't help but think that the difference in legislative ideas will not affect the total amount of taxes in essence. Is it necessary to treat taxpayers as bad people? Is this concept inherently problematic? To give an example, the crime of virtual invoicing is heavier than the criminal law of tax evasion, but it does not contain the illegal behavior. For example, a baby stroller with a brand in Japan can be used for two weeks before purchase. If it is not satisfied during the trial period, it can be returned unconditionally. Even so, the stroller did not suffer a lot of damage due to huge returns. If it is in China, such a marketing approach will inevitably lead to a lot of losses. From this it can be thought about whether this system has turned "good guys" into "bad guys". This kind of confrontation mechanism of "evil vs. evil" is the dissatisfaction expressed by taxpayers when they are unable to exercise their rights. Thus, the significance of establishing a trust mechanism is so great.

\section{INTRODUCTION TO THE TAXPAYER'S RIGHT TO PRESUMPTION OF HONESTY}

\section{A. The Concept of Taxpayer's Right to Presumption of Honesty}

The taxpayer's right to presumption of honesty is that in the case of taxation, setting up account books, etc., if there is no evidence to prove that the taxpayer violates the law and has been determined by law, it should be presumed that the taxpayer's tax payment and related behavior are honest, legal, and error-free. The provisions on the taxpayer's right to presumption of honesty are similar to the "presumption of innocence principle" in penal law. The taxpayer's right to presumption of honesty gives the burden of proof to the tax collector, and the taxpayer shall only bear the burden of proof when the tax collector has evidence to prove that his taxation or facts are illegal. And before the tax collector makes a decision on the treatment, the taxpayer has the right to make a statement, the right to defend, and the right to hear. After the tax collector makes a decision, the taxpayer has the right to relief according to law. And the tax collector shall, in the course of law enforcement, make decisions that are beneficial to the taxpayer within a fair and reasonable manner without violating the law.

The taxpayer's right to presumption of honesty is a passive, defensive right. As a kind of right to prevent the taxpayer from improperly disturbing, the taxpayer's right of presumption of honesty cannot actively interfere with the exercise of the taxation right.

The taxpayer's right to presumption of honesty is a relative right. The scope is limited to taxpayers in the field of tax law, and taxpayers have to claim rights from tax collectors. 


\section{B. Definition of Relevant Concepts of Taxpayer's Right to Presumption of Honesty}

The related concepts of the taxpayer's right to presumption of Honesty should be analyzed from the three independent but interrelated aspects of the subject, object and content of the right. The right subject is the tax obligor in the tax field, including the natural person, legal person and other organizations that should pay taxes according to law. The right object is the reliance interest of the taxpayer, and the content of the right is the concept of the taxpayer's right to presumption.

In addition, the relevant concepts of the taxpayer's right to presumption of honesty should also include the definition of the taxpayer, the tax collector and the tax spender. The concept of taxpayer is the above-mentioned tax obligor. The concept of tax collector is the party to exercise the tax collection and management right in the tax legal relationship, which conducts the tax collection according to law. It is specifically represented by the taxation department, the financial department and the customs in China. As the most easily overlooked concept, the concept of tax spender should be paid more attention. Under the conditions of market economy, the government uses the taxpayer's tax as a special industrial sector, not only enjoying rights, but also having obligation to provide taxpayers with public goods and services.

\section{Background Research on the Taxpayer's Right to Presumption of Honesty}

The background research of the taxpayer's right to presumption of honesty should be divided into two parts: one is the background research in the sense of jurisprudence, and the other is the background research in the sense of historical development.

As far as the background research on the legal significance of the taxpayer's right to presumption of honesty is concerned, it can be regarded as an extension of the three legal fields.

First, the taxpayer's right to presumption of honesty is the embodiment of the constitutional right to dignity in the field of tax law. Second, the "taxpayer's right to presumption of honesty" in the "tax statutory principle" is similar to the "presumption of innocence principle" in the "principles of legality" in the penal law. The "principles of legality" in the criminal law means that it is not a crime when the law (penal law) does not stipulate, and there is no punishment when there is no explicit provision in the law. It is based on the principles of legality prescribed punishment for crimes. In order to protect the legal rights of criminal suspects and defendants, the provisions of criminal suspects or defendants may not be considered guilty without evidence and before the ruling. Then, in detail, the "taxpayer's right to presumption of honesty" in the context of "tax statutory principle", the tax statutory principle refers to the basic principle of tax law that the legislator decides all tax issues, that is, if there is no corresponding law, the government cannot levy taxes, and the citizens also have no obligation to pay taxes. After the above comparison, it can be seen that the "taxpayer's right to presumption of honesty" in the "tax statutory principle" is similar to the "presumption of innocence principle" logic system in the "principles of legality" in the penal law. Third, the taxpayer's right to presumption of honesty is an inherent requirement of the principle of honesty and credit and the principle of equality in the field of civil law. The principle of honesty and credit and the principle of equality are legal norms with moral connotations. Applying this legal norm to the tax law requires the taxpayer to make taxation in accordance with the principle of honesty and integrity, and means that the rights and obligations of the tax collector and the taxpayer should be equal.

\section{The Significance of the Establishment of Taxpayer's Right to Presumption of Honesty System}

The taxpayer's right to presumption is a right in the field of tax law. It plays an important role in balancing the rights relationship between taxpayers, tax collectors and tax spenders. And by establishing a system of taxpayer integrity presumption, it can better improve taxpayer's tax compliance, bind tax authorities' rights, and improve credibility.

1) Balancing the rights of taxpayers, tax collectors, and tax spenders: The three concepts of taxpayers, tax collectors and tax spenders have been clearly distinguished in the previous section, and important subjects have been specifically explained. Here, this paper will further explore the importance of the taxpayer's right to presumption of honesty to balance the balance of rights among taxpayers, tax collectors and tax spenders. The tax spender is the most easily overlooked subject among the three, and has an important influence on the taxpayer's taxation behavior and the tax collector's taxation behavior. The taxpayer's right to presumption of honesty requires the tax collector to correctly locate the taxpayer, and must not make judgments against the taxpayer under the prescribed circumstances, and also to some extent achieve supervision over the use of taxpayers. This right plays an important role in balancing the relationship among taxpayers, tax collectors, and tax spenders.

2) Enhancing taxpayer's tax compliance and binding tax authorities' rights: Blindly taking taxation as a kind of obligation that requires the taxpayer implement is forceful. But once this mandatory obligation is turned into a right to be implemented, it can enhance the taxpayer's tax compliance and bind the tax authorities' rights. Taxpayers' rights basically include the following aspects: at the constitutional level, they agree on taxation rights, government service rights, and legal rights, right to know, privacy, tax savings, etc. of tax liability in tax activities. It agrees that taxation rights, statutory rights of taxation obligations, and tax savings rights play an important role in raising taxpayers' autonomous taxation consciousness and restricting government power and behavior. From the perspective of tax compliance subjects, raising the taxpayer's autonomous taxation consciousness determines 
taxpaying compliance, and restricting government power and behavior determines tax-collecting compliance and taxspending compliance. It can be seen that the taxpayer's rights, including the taxpayer's right to presumption of honesty, play a decisive role in improving the taxpayer's tax compliance and binding the rights of the tax authorities and improving the credibility.

3) Implementing the tax statutory principle: The change of tax law from "taxation according to law" to "tax statutory principle" means the change of taxation from "obligation" to "right". From the past "requiring taxpayers to legally pay taxes in accordance with the law" to "the tax levied by tax collectors must be prescribed by law", it can be seen that the protection of taxpayers' rights is being strengthened. The taxpayer's right to presumption of honesty as a guarantee for the taxpayer's rights is also a further implementation of the tax statutory principle.

\section{ANALYSIS OF THE IMPLEMENTATION STATUS OF THE} TAXPAYER'S RIGHT TO PRESUMPTION OF HONESTY IN CHINA

China's taxpayers' tax compliance is not high, and it has a great relationship with taxpayers' lack of rights awareness. Although the government has taken a series of measures to make taxation behavior easier, it has also increased penalties for non-taxable behavior. However, at the root of it, the taxpayer's tax compliance should start from the taxpayer itself and analyze the core issues affecting the taxpayer's tax compliance. It means that should be considered from the taxpayer's subjective initiative, focusing on whether the taxpayer's rights that should be enjoyed in the taxation behavior are protected and whether relief can be obtained.

\section{A. The Lack of Taxpayer's Right to Presumption of Honesty in the Legislative Field}

The taxpayer's right to presumption of honesty is a basic right of taxpayers and is not well reflected in the legislation.

The Tax Collection Administration Law clearly stipulates a number of rights for tax collectors, including inspection rights, tax preservation, and enforcement measures, etc. The scope of protection is broad and the rights of tax collectors are fully implemented. As for the taxpayer's rights, only the right to report is scatteredly stipulated, and the taxpayer's right to presumption of honesty is not mentioned. It also stipulates a series of obligations for taxpayers, including the obligation to accept tax inspections. It may well be asked, on the one hand, there are the tax collectors whose rights are far greater than the obligations, and on the other hand, there are the taxpayers whose obligations are far greater than the rights. So there is no so-called equality of rights and obligations of both parties.

\section{B. Insufficient Taxpayer's Right to Presumption of Honesty in the Field of Law Enforcement}

The taxpayer's right to presumption of honesty is a basic right of taxpayers and is not well reflected in law enforcement.
In practice, tax collectors often make unfair decisions against taxpayers based solely on guesswork. Although some decisions did not directly affect the taxpayer's substantive rights, at this time, the tax collectors violated the taxpayer's right to presumption of honesty, which led to the waste of judicial resources, and has made taxpayers have bad thoughts on government credibility. These behaviors that should not have happened can be avoided based on the taxpayer's right to presumption of honesty. Moreover, in practice, when tax collectors do not enforce the law in a civilized way and violate procedural rules, such as abuse of power and not showing documents according to law, they are wasting judicial resources and have an adverse impact on government credibility. These can also be avoided by complying with the taxpayer's right to presumption of honesty.

\section{Reasons for the Lack of Taxpayer's Right to Presumption of Honesty}

In China, the reasons for the lack of taxpayer's presumption of honesty contain many aspects, including historical, economic, social and other reasons.

From a historical point of view, China's liberation lacks the initiative to fight for people's own rights. Moreover, since ancient times, China has had an "official standard" mode of thinking, which the nature is deeply rooted of regarding taxpayers as "serving for bureaucrats". And the taxpayer's awareness of rights is not strong enough. Although China has developed to this day, there is still some influence.

From an economic point of view, China is in the transition period from a planned economy to a market economy. The establishment of a taxpayer's presumption of honesty may increase the pressure on tax collectors, and because of the incomplete rigor, unlimited expanding the rights of taxpayers may lead to a small number of taxpayers using the "vulnerabilities" of the law to conduct illegal taxation. Fan Bingbing's tax evasion example is a reflection of this.

From a social point of view, the taxpayer's right to presumption of honesty needs to rely on a large honest social environment. This kind of trust includes the tax collector's trust in the taxpayer, and also the taxpayer's trust in the tax collector. These two are mutual. From practice, it can be appreciated that the degree of trust between the two is generally low, and both sides have a cautious and hostile attitude towards each other. This is unfavorable for establishing the taxpayer's right to presumption of honesty.

\section{The Impact of the Loss of Taxpayer's Right to Presumption of Honesty on China}

In fact, the influence of the taxpayer's right presumption of honesty on China is very similar to the above-mentioned significance of the establishment of the taxpayer's right to presumption of honesty system. However, many scholars have many concerns about the lack of the taxpayer's right to presumption of honesty. 
Against the background of modern state governance and modern democratic politics, only paying attention to the rights of taxpayers, especially the protection of basic human rights including the taxpayer's right to presumption of honesty, and combining national interests, taxpayer interests, and social interests, can the legislation and implementation of the tax law present a "benign" situation and achieve rationality. Some scholars pointed out that the Chinese tax law in the new century should firstly be based on the core position of the taxpayer's rights. This is not only the significance of democracy and the rule of law, but also the need for stable and sustainable development of the market economy. China should reshape the concept of taxation and construct a taxation rule of law based on the rights of taxpayers.

\section{EXPLORING THE PROTECTION METHOD OF THE TAXPAYER'S RIGHT TO PRESUMPTION OF HONESTY IN OVERSEAS}

The differences in national culture, social background, social civilization, and historical processes of various countries and the different legal backgrounds have led to differences in the legislative protection of taxpayers' right to presumption of honesty. Furthermore, the legislative protection of taxpayer's right to presumption of honesty in Korea, Japan, Australia, Canada, the United Kingdom, and the United States will be further analyzed, which will serve as a reference for the establishment of the system of taxpayer's right to presumption of honesty.

Here, the explicit prescribed model and implicit prescribed model in the legislative protection of the taxpayer's right to presumption of honesty are discussed separately and how countries that adopt different legislative protections applying the law are also listed.

\section{A. The Explicit Prescribed Model of Taxpayer's Right to Presumption of Honesty}

Countries with such explicit prescribed model include South Korea, Australia, Canada, the United Kingdom and other countries, and here are the most representative regulations of the above countries.

1) South Korean legislative protection of taxpayer's right to presumption of honesty: The taxpayer's right to presumption of honesty is clearly defined in the "Taxpayer's Rights Charter" in South Korea. In June 1997, the Korean "Taxpayers' Rights Charter" was enacted, which stipulated seven rights that taxpayers should enjoy. The first article is the taxpayer's right to presumption of honesty, which stipulates that "taxpayers shall be deemed to be honest in the case of setting up account books according to law and truthfully reporting, and the tax information provided shall also be regarded as real information."

The "Taxpayers' Rights Charter" adopts seven rights including taxpayer's right to presumption of honesty, aiming at safeguarding the rights of taxpayers and realizing the comprehensive protection of taxpayers' rights by protecting the rights of taxpayers.
2) Australian legislative protection of taxpayer's right to presumption of honesty: The "Taxpayer's Charter" in Australia also expressly defines the taxpayer's right to presumption of honesty. Australia's "Taxpayer's Charter", issued in July 1997, states: "We assume that what the taxpayer tells us is true unless we have reason to believe that it is not." This provision clarifies that taxpayers enjoy the right to presumption of honesty that is similar to the presumption of innocence. It can be seen that the "Charter" has the characteristics of humanization, standardization, legalization and concreteness in the protection of taxpayers' rights.

3) Canadian legislative protection of taxpayer's right to presumption of honesty: Canada also has explicit provisions on the taxpayer's right to presumption of honesty in the "Taxpayer's Rights Declaration". In 1985, Canada's "Taxpayer's Rights Declaration" stated: "We assume that what the taxpayer tells us is true unless we have reason to believe that it is not." This provision emphasizes that tax authorities can only fight against taxpayers who are presumed to be honest when they have "proof of evidence".

4) British legislative protection of taxpayer's right to presumption of honesty: The United Kingdom also stipulates the taxpayer's right to presumption of honesty in the form of law. Article 4, paragraph 3, of the "Charter of the Royal Tax and Customs Office" expressly states: "The taxpayer has the right to be presumed to be an honest taxpayer, and the taxpayer is also obliged to deal with the taxation matters honestly." While clearly stipulating the taxpayer's right to presumption, it also clearly stipulates the taxpayer's obligations. This law balances the rights and obligations between tax collectors and taxpayers, and it is more rigorous.

\section{B. Implicit Prescribed Model of Taxpayer's Right to Presumption of Honesty}

The implicit prescribed model of the taxpayer's right to presumption of honesty is that it does not expressly stipulate in the law that the taxpayer should have or enjoy the right to presumption of honesty, but according to other regulations, the essential meaning of the right to presumption of honesty can be presumed.

Among the countries that have implicitly defined the taxpayer's right to presumption of honesty, the United States are the most typical. The United States is a case law system country. Although there is no explicit "taxpayer's right to presumption of honesty" in its law, Article 3 of the US "Taxpayer's Rights Act", which was enacted in 1988, states: "Taxpayers have the right to enjoy professional and courteous services. Denying the taxpayer's honesty can be considered rude, and taxpayers have the right to complain or sue to the tax authorities." It can be seen that the United States adopts an implicit prescribed model for the taxpayer's right to presumption of honesty. 


\section{The Enlightenment of Foreign Countries' Legislation Protection of Taxpayer's Right to Presumption of Honesty to China}

Through the analysis of the legislative protection of the above five countries (including the explicit prescribed model and the implicit prescribed model), it can be seen that different countries have different system of taxpayer's right to presumption of honesty in different contexts. This has certain reference significance for the establishment of the system of taxpayer's credit presumption in China.

China should make full use of the useful experience of South Korea, Australia, Canada, the United Kingdom and the United States. China can adopt the principle of changing the taxpayer's right to presumption of honesty from "obligation" to "right", increase taxation propaganda, establish self- and social assessment mechanisms, and strengthen the feedback mechanism as well as the appropriately increase the rights relief mechanisms, etc. While restricting public rights to protect private rights, attention should be paid to restricting the infinite expansion of private rights and maintaining a stable relationship between the two.

\section{ESTABLISHING THE FRAMEWORK OF CHINA'S} TAXPAYER'S RIGHT TO PRESUMPTION OF HONESTY

The previous context has made a brief analysis of the inadequacies of the taxpayer's right to presumption of honesty in China. After analyzing the legislative protection of the extraterritorial taxpayer's presumption of infringement, based on the purpose of drawing useful experience, this paper analyzes the enlightenment of the legislative protection of the territorial taxpayer's right to presumption of honesty, which can be expressed in four aspects. In this chapter, the issue of establishing the structure of the taxpayer's integrity presumption in China will be further explored and recommendations will be made.

\section{A. Promoting from Three Aspects: Legislation, Law Enforcement and Judiciary}

The tax law needs the support of the legal system to protect the rights of taxpayers. The basic rights of taxpayers are, to a certain extent, rights in the constitutional sense and the embodiment of the right to constitutional dignity. However, if this right is not expressly provided by law, it will definitely become an ineffectual right to be built on stilts. Only under the premise that the concept of taxpayer's rights is established, through the logic shortcut of constitutional amendment and legal amendment to bring the basic rights of taxpayers into the constitution and law, can it demonstrate the spirit of the taxpayer's rights standard from the perspective of the rule of law and build a taxpayer's rights system.

As far as perfecting law enforcement is concerned, the tax collector should be required to implement the content of the taxpayer's right to presumption of honesty in the law enforcement process, that is, the decision that is unfavorable to the taxpayers should not be made without sufficient evidence. And in the taxation procedure, the tax system should be simplified to fully protect the rights of taxpayers in response to the taxpayer's rights system.

In terms of improving the judiciary, the taxpayer's right to relief should be increased. The case for entering the proceedings should be taken over by the professional review department, and the taxpayer should be given adequate relief procedure rights and relief entity rights. In the case that the taxpayer's right to presumption of honesty is violated, in the process of implementing the taxpayer's right to presumption, the rightfulness of such rights should be clarified to ensure the overall good operation of the taxpayer's right to presumption of honesty.

\section{B. Establishing the Subjective Initiative of Taxpayers, Tax Collectors, and Tax Spenders}

The subjective initiative of the taxpayer, the tax collector, and the tax spender's tripartite subject is of great significance for establishing the structure of the taxpayer's right to presumption of honesty. The specific content should be expressed as:

As citizens, natural persons or other organizations as taxpayers, they should have "taxpayer awareness" because taxpayers and tax spenders are two concepts that cannot be separated. As it mentioned earlier, taxpayers have the right to supervise the tax spenders' use of taxes.

The taxation authorities as the tax collectors shall have "the concept of tax collectors" and the tax collectors shall have some knowledge of the amount that should be levied according to law. Moreover, because taxation is a legally generated obligation of taxpayers enjoying public goods or services, taxpayers are not only tax obligors but also enjoyers of public goods or services.

The government departments that act as tax spenders should have the "tax spenders' consciousness". When exercising taxation rights, the tax spenders should be aware that such rights are not unrestricted, but are always subject to the supervision of the tax obligors.

\section{Changing from "Official Standard Consciousness" to "People-oriented Consciousness"}

The establishment of a system from the "official standard consciousness" to the "people-oriented consciousness" is correcting name for traditional Chinese thought. The "official standard consciousness" that has been passed down from ancient times has been deeply rooted, and this kind of thinking is very unfavorable to protect the rights of taxpayers. Therefore, fundamental improvements must be made. This is essentially a shift in the concept of tax collection and management. The main focus should be on multiple aspects like intensifying taxation propaganda, establishing selfassessment and social assessment mechanisms, strengthening feedback mechanisms, and strengthening supervision while expanding taxpayer rights, etc.

Now citizens' awareness of taxpaying rights is weak, and tax promotion should be strengthened. Intensifying taxation propaganda will not only inform taxpayers of the obligations that taxpayers should enjoy according to law, but also 
popularize the rights that taxpayers should enjoy according to law. The beneficial combination of the two can enable taxpayers to fully understand their rights and obligations that they should enjoy according to law.

For the taxation of tax collectors, a good self-assessment and social assessment mechanism should be established to enable taxpayers to participate in the tax collectors' behaviors. At the same time as the evaluation mechanism is established, tax collectors and tax spenders should establish a feedback mechanism for the society, and regularly publish the necessary information on the subject and amount of taxation to the public by announcement or other forms, and increase the credibility.

\section{Improving the Distribution of the Burden of Proof}

Improving the distribution of the burden of proof between taxpayers and tax collectors is the core issue of comprehensively implementing the taxpayer's right to presumption of honesty. If the issue of the distribution of burden of proof is not well improved, the tax system of the taxpayer's rights-based system will certainly not be able to set up. The implementation of the right to presumption of honesty should be divided into two aspects on this basis: on the one hand, the tax collectors should prove that the taxation act is illegal, and this is to limit the abuse of the taxpayer; on the other hand, the tax collector's proof of the taxpayer's illegal behavior should be staged, and the specific circumstances should be analyzed in detail to prevent taxpayers from using this "rights awareness" to conduct tax evasion. These two aspects are the mutual restraint and balance between the rights of taxpayers and tax collectors. This will help to better establish the system framework of taxpayer's right to presumption of honesty.

\section{CONCLUSION}

To sum up, in the context of modern governance, it is necessary to abandon the positioning of the traditional "management law", and guide the basic positioning of the "governance law" and "service law" centered on taxpayers and take the road to the legislative purpose of promoting compliance. Under this circumstance, the honest presumption of power is clearly defined in the tax collection and administration law.

\section{REFERENCES}

[1] Gao Peiyong, Taxpayer, Tax Collector, Tax Spenders: Reflections on the Issue of "Ruling Tax by Law" [J]. International Taxation In China, 2000 (04): 5 - 8. (in Chinese)

[2] Liu Jianwen, Taxpayer Rights Protection: Opportunities and Challenges [J]. International Taxation In China, 2010 (05): 5 - 8. (in Chinese)

[3] Zhang Xin, Analysis of the "Taxpayer" Rights [J]. China Economic Studies, 2003 (01): 13 - 23. (in Chinese)

[4] Wang Wei, On Safe Guarding the Right of Taxpayer to Promote Tax Compliance in China [J] Taxation Research Journal, 2008 (04): 70 74. (in Chinese)

[5] Shi Zhengwen, On the Privilege of the Tax Programme [J]. Taxion and Economy (Journal of Jilin University of Finance and Economics, 2003 (01): 42 - 46. (in Chinese)
[6] Shi Zhengwen, On the Power to Impose and the Right to Pay Tax [J] China Legal Science, 2002 (06): 145 - 155. (in Chinese)

[7] Zhang Shouwen, Tax System Changes and Modernization of Tax Law [J]. Social Sciences in China, 2015 (02): 80 - $102+204$. (in Chinese)

[8] Zhao Zhenhua, Views About the Procedural Antagonistic Right of the Administrative Relative Person [J]. Legal Forum, 2000 (03): 23 - 27. (in Chinese)

[9] Zhang Shouwen, Harmony of the Reform of Tax Law and the Order of Private Law [J]. Jurists Review, 2004 (05): 25 - 30. (in Chinese)

[10] Liu Jianwen, Song Li, Several Important Issues in the Tax Administration Law [J]. Lawyer World, 2002 (09): 4 - 9. (in Chinese)

[11] Tan Zhizhe, On the Restriction of China's Tax Legislation Power Also on the Legal Interpretation of Article 56 of the Constitution [J]. Social Scientist, 2012 (03): 105 - 108. (in Chinese)

[12] Weng Wuyao, Lan Xin, Zhou Yuxin, The Protection of Foreign Taxpayers' Rights and Its Legislation [J]. Graduate Law Review.cupl, 2017, 32 (03): 1 - 18. (in Chinese)

[13] Gu Jinjun, One Charter Two Systems South Korea Makes a "Double Insurance" for Taxpayers [J]. China Taxation, 2001 (07): 47. (in Chinese)

[14] Huang Qian, The Enlightenment of Australian Taxpayer Charter on Improving the Rights of Taxpayers in China [J]. China Commerce, 2010 (02): 302. (in Chinese)

[15] Zhu Daqi, Li Shuai, Taxpayer's Right to Presumption of Honesty: Analysis,Source and Structure - and Comments to the Draft of the Law on Administration of Tax Collection [J]. Wuhan University Journal (Social Sciences), 2015, 68 (06): 119 - 126. (in Chinese)

[16] Zhang Fuqiang, The Logical Path of Taxpayers' Right into China's Constitution [J]. Tribune of Political Science and Law, 2017, 35 (04): 168 - 175. (in Chinese)

[17] Chen Bing, On the Reform of China's Tax Collection and Management Law Model under the Perspective of Globalization An Interpretation Based on the Collection and Management of Internet Transaction Tax [J]. Journal of Sun Yatsen University (Social Science Edition), 2015, 55 (06): 171 - 186. (in Chinese)

[18] Wang Huayu, On the Taxpayer's Honest Presumption of Power in Tax Law [J]. Taxation Research, 2014 (01): 68 - 71. (in Chinese)

[19] Liu Jianwen, Several Basic Issues in the Amendment of the Tax Collection Management Law: Focusing on the Protection of Taxpayers' Rights [J]. Law Science, 2015 (06): 3 - 12. (in Chinese) 